\title{
PRINSIP-PRINSIP KEPEMILIKAN SAHAM PEMERINTAH DALAM \\ PERUSAHAAN MILIK NEGARA \\ (STUDI PERBANDINGAN ANTARA INDONESIA DENGAN SINGAPURA)
}

Oleh:

Ni Wayan Desi Aryanti

Mahasiswa Magister Ilmu Hukum Unud

\begin{abstract}
This journal entitled "Comparative Study Concerning The Principles of Government's Shares in State Owned Enterprise”. Problems being research in this thesis are, first: the legal standing of the state's equity in Persero according to Indonesian corporate law and its comparison to Singapore corporate law. The second problem, what are legal implications of the government's shares in Persero.

The method being used is normative legal research through legislation and regulation approach and comparative approach. Legal materials used are primary legal materials, legal materials and secondary and tertiary legal materials, the analysis done by descriptive, evaluative, interpretative, analytical and argumentative.

This research shows that according to Indonesian corporate law, the state's equity being placed in Persero belongs to Persero and according to Singapore Law, the government's equity being placed in Persero as the Government Linked Company belongs to the said company. Legal consequences of the government equity in Persero are: the management of the said equity is no longer subject to state budget's principals but to good corporate government principals; contracts made by Persero binds Persero and not the government, hence compliance and liability arising from the said contracts are Persero's liability only and therefore Persero's claim arising from contracts belong to the said Persero. However, in practical level, there are still some inconsistency in Persero's equity treatment (i.e. financial audit and Persero's inability to act as the guarantor to another company).

On the other side, the Government of Singapore's equity in Temasek is managed by corporate mechanism and almost without government intervention (except for past reserves). Therefore Temasek is free to make any contract with third parties and can act as the guarantor for its subsidiary.
\end{abstract}

Key Words: State's Equity, Persero, Government Linked Company, Temasek.

\section{PENDAHULUAN}

\section{Latar Belakang}

Perekonomian Indonesia ditopang oleh 3 pilar utama yakni koperasi, BUMN dan swasta. ${ }^{1}$ Terdapat dua bentuk

\footnotetext{
${ }^{1}$ Berdasarkan ketentuan Pasal 1 angka 1 UU No. 19 Tahun 2003, Badan Usaha Milik Negara, yang selanjutnya disebut BUMN, adalah badan usaha yang
}

BUMN, yakni Perusahaan Perseroan

(Persero) dan Perusahaan Umum

(Perum). Berdasarkan ketentuan Pasal 1 angka 2 UU No. 19 Tahun 2003, Persero adalah BUMN yang berbentuk perseroan

seluruh atau sebagian besar modalnya dimiliki oleh negara melalui penyertaan secara langsung yang berasal dari kekayaan negara yang dipisahkan. 
terbatas yang modalnya terbagi dalam saham yang seluruh atau paling sedikit lima puluh satu persen sahamnya dimiliki oleh Negara Republik Indonesia yang tujuan utamanya mengejar keuntungan. Contoh Persero antara lain PT Pertamina (Persero), PT PLN (Persero) dan PT Bank Mandiri (Persero) Tbk.

Terdapat 141 BUMN, baik berbentuk Perum maupun Persero. Namun demikian, sampai dengan tahun 2009, 24 BUMN masih mencatatkan kerugian dengan jumlah total 1,72 trilyun rupiah. $^{2}$

Inefisiensi dalam pengelolaan BUMN utamanya yang berbentuk Persero bisa jadi disebabkan oleh masuknya kekayaan Negara dalam Persero. Masuknya kekayaan Negara di dalam Persero berkaitan dengan keuangan negara. Selain itu, karena Persero berbentuk PT maka ketentuan-ketentuan yang berlaku terhadap PT umumnya berlaku untuk Persero. ${ }^{3}$

Dengan demikian, apabila Persero tunduk pada ketentuan UU No. 40 tahun 2007, seharusnya kekayaan negara yang disertakan ke dalam Persero adalah kekayaan yang terpisah. Namun demikian, Pasal 2 huruf g UU No. 17 tahun 2003 mengatur bahwa kekayaan

\footnotetext{
${ }^{2}$ Kementerian Badan Usaha Milik Negara, Laba Rugi, available at: http://www.bumn.go.id/kinerjabumn/laba-rugi/, accessed 07 Oktober 2013

3 IG Rai Widjaja, 1994, Pedoman Dasar Perseroan Terbatas (PT), Pradnya Paramita, Jakarta, h.72.
}

yang disertakan Persero adalah keuangan negara.

Penyertaan negara dalam BUMN tidak hanya terjadi di Indonesia. Pemerintah negara Singapura juga membentuk Government Linked Company (GLC) untuk meningkatkan perekonomian negaranya. Salah satu yang paling terkenal adalah Temasek Holding Pte. Ltd.

Temasek adalah salah satu diantara sedikit perusahaan yang mendapat rating Aaa dari Moody's. ${ }^{4}$ Adapun Standard and Poor's Rating Service memberikan credit rating AAA bagi Temasek. ${ }^{5}$

Karakter Temasek sebagai GLC yang dibentuk pemerintah Singapura mirip dengan Persero yang merupakan BUMN yang dibentuk oleh pemerintah. Namun perbedaan performance yang sangat besar diantara keduanya membuat pembahasan mengenai perbandingan prinsip-prinsip kepemilikan saham pemerintah dalam usaha milik negara di

4 Moody's Investor Service, Credit Opinion: Temasek Holdings (Private) Limited, Available at. http://www.temasek.com.sg/Documents/userfiles/files/ Moody's_Ratings_Update_5_Dec_12.pdf, Accessed 18 September 2013.

${ }^{5}$ Diberikannya credit rating AAA dengan dasar bahwa Temasek memiliki excellent business risk. Temasek memiliki portfolio investasi yang beragam baik secara geografis maupun jenis industry, konsisten dalam menghasilkan keuntungan dari investasi yang bersifat liquid dan memiliki investasi di perusahaanperusahaan dengan rating $\mathrm{A}$ atau lebih tinggi.

Standard and Poor's Rating Service, Rating Direct, Summary Temasek Holding (Private) Limited, Available http://www.temasek.com.sg/Documents/userfiles/files/ SP_Temasek_SA_2013_Jun_28.pdf, accessed at 18 September 2013. 
Indonesia dan Singapura menjadi

menarik.

\section{Rumusan Masalah}

Berdasarkan latar belakang masalah yang telah diuraikan sebelumnya maka permasalahan yang dapat dirumuskan sebagai berikut:

a. Bagaimanakah kedudukan harta kekayaan Negara yang dimasukkan dalam Persero dalam perspektif hukum perseroan dan perbandingannya dengan hukum perseroan Singapura?

b. Bagaimanakah akibat hukum kepemilikan saham pemerintah dalam Persero?

\section{Tujuan Penelitian}

a. Tujuan umum

Untuk mengetahui perbandingan prinsip-prinsip kepemilikan saham pemerintah dalam Persero.

b. Tujuan khusus

1) Untuk mengetahui kedudukan harta kekayaan Negara yang dimasukkan dalam Persero dalam perspektif hukum perseroan dan perbandingannya dengan hukum perseroan Singapura.

2) Untuk mengetahui akibat hukum kepemilikan saham pemerintah dalam Persero.

\section{METODE PENELITIAN}

Pengkajian mengenai masalah akibat hukum kepemilikan saham pemerintah dalam Persero merupakan penelitian yuridis normatif yakni merupakan suatu pendekatan dalam pemecahan masalah dengan cara "pendekatan menggunakan legislasi dan regulasi (the statute approach)". ${ }^{6}$ Selain itu digunakan pula pendekatan komparatif.

Oleh karena penelitian ini merupakan penelitian hukum normatif, maka mengandalkan penggunaan bahan hukum primer, sekunder dan tertier. ${ }^{7}$ Dalam penelitian hukum, ketiga bahan hukum tersebut disebut data sekunder yang memiliki kekuatan mengikat ke dalam. ${ }^{8}$

Data dikumpulkan dengan teknik studi kepustakaan. Analisis terhadap bahan-bahan hukum dilakukan dengan cara deskriptif, analisis, evaluatif, interpretatif dan argumentatif.

\section{HASIL DAN PEMBAHASAN}

1. Harta kekayaan Negara yang dimasukkan dalam Persero dalam perspektif hukum Indonesia

Persero adalah BUMN yang berbentuk Perseroan Terbatas, dengan demikian tunduk pada ketentuan dalam

6 Peter Mahmud Marzuki, 2009, Penelitian Hukum, Kencana Prenada Media Group, Jakarta, h.97.

7 Bahan hukum primer adalah bahan-bahan hukum yang bersifat mengikat, bahan hukum sekunder adalah bahan hukum yang memberikan penjelasan mengenai bahan hukum primer dan bahan hukum tertier adalah bahan hukum yang memberikan petunjuk atau penjelasan terhadap bahan hukum primer dan sekunder.

Soerjono Soekanto dan Sri Mamudji, 2001, Penelitian Hukum Nornatif Suatu Tinjauan Singkat, PT RajaGrafindo Persada, Jakarta, h.13.

8 Bambang Sunggono, 2006, Metodologi Penelitian Hukum, PT RajaGrafindo Persada, Jakarta, h.113. 
UU No. 40 tahun 2007. Sebagai

Perseroan Terbatas, Persero adalah badan hukum.

Berdasarkan teori organ oleh Otto Van Gierke, badan hukum adalah fakta yang sebenarnya sama seperti manusia dalam hukum. Badan hukum dianggap memiliki keinginan yang terpisah dengan pendirinya yang dibentuk melalui pengurusnya. Apa yang diputuskan oleh pengurus, adalah keinginan badan hukum. ${ }^{9}$

Sebagai subjek hukum, maka badan hukum itu nyata, sebagaimana orang sebagai subjek hukum. Jika manusia bertindak dengan organ tubuhnya, maka badan hukum bertindak melalui organ (pengurusnya). Perbuatan pengurus tersebut bukanlah sebagai individu melainkan untuk dan atas nama badan hukum sehingga apabila dilakukan perbuatan hukum, maka perbuatan tersebut bukanlah bukanlah perbuatan organ sebagai individu, melainkan badan hukum tersebut. ${ }^{10}$

Badan hukum memiliki ciri-ciri sebagai berikut: ${ }^{11}$

1. Terbatasnya tanggung jawab

2. Perpetual Succession

3. Memiliki kekayaan sendiri

9 R. Ali Ridho 2001, Badan Hukum dan Kedudukan Badan Hukum Perseroan, Perkumpulan, Korporasi, Yayasan, Wakaf, Alumni, Bandung, h.8

10 Chidir Ali, 1999, Badan Hukum, Alumni, Bandung, h. 33

${ }^{11}$ Ridwan Khairandy, Konsepsi Kekayaan Negara Dipisahkan dalam Perusahaan Perseroan, Jurnal Hukum Bisnis, Vo.26-No.1, 2007, h.33.
4. Memiliki kewenangan kontraktual

5. Dapat menuntut dan dituntut atas nama dirinya sendiri.

Ciri-ciri khusus Perseroan Terbatas tersebut bermuara dari adanya pemisahan kekayaan antara pemegang saham dan perseroan itu sendiri. Kepemilikan badan hukum atas suatu kekayaan, bersumber dari kekayaan yang dipisahkan oleh pemegang saham. $^{12}$

Perseroan Terbatas merupakan kumpulan atau asosiasi modal. Semua perbuatan hukum yang dilakukan oleh Perseroan Terbatas dipertanggungjawabkan dengan harta kumpulan modal yang tercermin dalam harta kekayaan perseroan tersebut, tanpa perlu memperhatikan siapa yang merupakan pihak yang menyisihkan modal atau yang mengambil bagian dari modal perseroan. ${ }^{13}$

Oleh karenanya, perseroan dianggap sebagai subjek hukum yang berbeda dengan pemiliknya. Sehingga, pemegang saham memiliki tanggung jawab yang terbatas, hanya sebatas saham yang dimiliki, kecuali terpenuhi kondisi

\footnotetext{
${ }^{12}$ Dengan dipisahkannya harta kekayaan tersebut oleh pemiliknya, harta kekayaan yang dipisahkan tersebut beralih kepemilikannya dari orang perorangan kepada badan hukum.

Gunawan Widjaja, 2008, Resiko Hukum Sebagai Direksi, Komisaris dan Pemilik PT, Forum Sahabat, Jakarta, h.2-3.

13 Gunawan Widjaja, 2008, Hak Individu dan Kolektif Para Pemegang Saham, Forum Sahabat, Jakarta, h.2.
} 
sebagaimana dimaksud dalam Pasal 3 ayat (2) UU No. 40 tahun 2007. ${ }^{14}$

Dengan terbatasnya tanggung jawab, hal tersebut berarti Perseroan dapat berkontrak dengan pihak ketiga atas namanya sendiri, kontrak tersebut hanya mengikat perseroan, bukan pemegang saham. Dalam hal ini, Perseroan adalah subjek hukum yang memiliki hak dan kewajiban sendiri yang terpisah dengan pemiliknya (pemegang saham). Lebih lanjut, pemisahan kekayaan ini juga mengakibatkan eksistensi Perseroan tidak tergantung pada pemegang sahamnya. Sekalipun saham perseroan dipindahtangankan, perseroan tetap ada. Dengan demikian, kekayaan yang terpisah merupakan ciri utama Perseroan.

Dalam kaitannya dengan Persero, maka Persero sebagai Perseroan Terbatas adalah suatu badan hukum yang modalnya terbagi atas saham. Sehingga, kekayaan yang disertakan oleh

${ }^{14}$ Berdasarkan ketentuan pasal 3 ayat (2) UU No. 40 tahun 2007, pertanggungjawaban terbatas pemegang saham tidak berlaku apabila:

a. persyaratan Perseroan sebagai badan hukum belum atau tidak terpenuhi;

b. pemegang saham yang bersangkutan baik langsung maupun tidak langsung dengan itikad buruk memanfaatkan Perseroan untuk kepentingan pribadi;

c. pemegang saham yang bersangkutan terlibat dalam perbuatan melawan hukum yang dilakukan oleh Perseroan; atau

d. pemegang saham yang bersangkutan baik langsung maupun tidak langsung secara melawan hukum menggunakan kekayaan Perseroan, yang mengakibatkan kekayaan Perseroan menjadi tidak cukup untuk melunasi utang Perseroan. pemerintah ke dalam Persero adalah kekayaan yang terpisah dan bukan lagi merupakan kekayaan negara. Hal ini sejalan dengan ketentuan UU No. 19 tahun 2003. ${ }^{15}$

Dengan demikian, berdasarkan hukum perseroan Indonesia, kekayaan negara yang disertakan ke dalam Persero adalah kekayaan Persero dan bukan lagi kekayaan negara. Namun demikian, ketentuan dalam UU No. 17 tahun 2003 mengaburkan kedudukan kekayaan negara yang dipisahkan tersebut. Ketentuan Pasal 2 huruf g menentukan bahwa ruang lingkup keuangan negara diantaranya meliputi kekayaan yang dipisahkan pada perusahaan negara/ perusahaan daerah.

Selanjutnya, Pasal 1 angka 1 UU No. 1 tahun 2004 menyebutkan bahwa investasi dan kekayaan negara yang dipisahkan termasuk dalam lingkup perbendaharaan negara.

Dengan demikian, UU No. 17 tahun 2003 dan UU No. 1 tahun 2004 telah mengaburkan batas tegas kekayaan negara yang disertakan dalam Persero.

${ }^{15}$ Berdasarkan ketentuan Pasal 4 ayat (1), "Modal BUMN merupakan dan berasal dari kekayaan negara yang dipisahkan"

Penjelasan Pasal 4 ayat (1) UU No. 19 tahun 2003: Yang dimaksud dengan dipisahkan adalah pemisahan kekayaan negara dari Anggaran Pendapatan dan Belanja Negara untuk dijadikan penyertaan modal negara pada BUMN untuk selanjutnya pembinaan dan pengelolaannya tidak lagi didasarkan pada sistem Anggaran Pendapatan dan Belanja Negara, namun pembinaan dan pengelolaannya didasarkan pada prinsip-prinsip perusahaan yang sehat. 
Padahal hukum perseroan secara tegas menentukan bahwa kekayaan negara yang dipisahkan tersebut bukan lagi kekayaan negara, melainkan merupakan kekayaan Persero. Hal inilah yang kemudian membawa implikasi atas tindakan-tindakan hukum yang dilakukan oleh Persero, yang akan dijelaskan lebih lanjut pada bagian kedua tulisan ini.

Di Singapura, perusahaan milik negara terdiri dari dua komponen utama, yakni Government Linked Company ("GLC") dan Government Statutory Boards. GLC adalah suatu badan hukum yang seluruh sahamnya dimiliki oleh Temasek Holdings atau dimana Temasek Holdings secara langsung memiliki saham pengendali. ${ }^{16}$

Perusahaan berdasarkan ketentuan the Singapore Companies Act adalah entitas bisnis yang didaftarkan berdasarkan ketentuan the Singapore Companies Act. Berdasarkan ketentuan Pasal 4, perusahaan adalah badan hukum yang memiliki identitas terpisah dengan pemilik mapun pengurusnya. Sehingga perusahaan dianggap sebagai artificial person yang diciptakan oleh hukum. ${ }^{17}$

${ }^{16}$ Ha Joon Chang, 2007, State Owned Enterprise Reform, United Nation Department For Economic And Social Affair, h. 9.

17 Accounting and Corporate Regulatory Authority, Legal Nature of Companies, Available at: http://www.acra.gov.sg/NR/rdonlyres/EA3B81CAB14B-4B1F-A8FD00A9609DD5CD/0/LegalNatureofCompanies.pdf, Accessed 15 Juni 2013.
Temasek Holdings (Private) Limited (Temasek) adalah perusahan yang mengelola kekayaan pemerintah Singapura yang memiliki fokus pada pengembangan modal, restrukturisasi dan divestasi. ${ }^{18}$ Temasek didirikan berdasarkan the Singapore Companies Act pada tahun 1974 untuk menguasai dan mengelola investasi dan aset-aset yang sebelum dikuasai oleh pemerintah Singapura. Tujuan pengalihan asset-aset tersebut kepada perusahaan komersial adalah untuk membebaskan Kementerian Keuangan dari tugas pengelolaan investasi dan fokus pada peran utamanya sebagai pembuat kebijakan dan aturan, sementara Temasek menguasai dan mengeloala investasi tersebut dengan prinsip-prinsip komersial. ${ }^{19}$

Oleh karena Temasek didirikan berdasarkan the Singapore Company Act, maka Temasek tunduk pada ketentuan the Singapore Company Act tersebut.

Temasek merupakan exempt private company. Exempt private company merupakan private limited company yang memiliki tidak lebih dari 20 pemegang saham dan tidak satupun dari pemegang sahamnya adalah perusahaan atau yang

18 Bloomberg Business Week, Company Overview of Temasek Holdings (Private) Limited, Available http://investing.businessweek.com/research/stocks/priv ate/snapshot.asp?privcapId=107637, Accessed 15 Juni 2013.

${ }^{19}$ Anonim, Temasek Frequently Asked Questions, Available at: http://www.temasek.com.sg/faqs, Accessed 16 Juni 2013. 
seluruh sahamnya dimiliki oleh pemerintah dan dinyatakan sebagai exempt private company dalam lembaran negara. ${ }^{20}$

Sebagai exempt private company, pada dasarnya Temasek merupakan private limited company dengan beberapa pengecualian sebagaimana disebut di atas. Berdasarkan ketentuan Pasal 18.1 the Singapore Company Act, sebuah perusahaan yang memiliki modal dalam bentuk saham dapat dinyatakan sebagai exempt private company apabila dalam anggaran dasarnya membatasi hak pengalihan saham; membatasi jumlah pemegang saham tidak lebih dari 50 dan melarang adanya public offer atas saham atau obligasi.

\section{Private limited company} merupakan badan hukum mandiri yang terpisah dari pemiliknya, bisa dituntut maupun menuntut atas namanya sendiri, dan direksi serta pemegang saham perusahaan tidak bertanggungjawab atas utang perusahaan. Pembatasan tanggung jawab ini bukan berarti bahwa terbatasnya tanggung jawab perusahaan terhadap kreditur, melainkan tanggung jawab pemegang saham atau pengurusnyalah yang terbatas. Sepanjang penyertaan modal dalam bentuk saham

20 Accounting and Corporate Regulatory Authority, Private Company Limited by Shares, Available http://www.acra.gov.sg/Company/Starting_a_Company /Types+of+Companies.htm, Accessed 15 Juni 2013. dibayar lunas, pemegang saham tidak memiliki kewajiban lainnya terhadap kreditur perusahaan dan harta pribadinya dilindungi dari kreditur-kreditur tersebut. $^{21}$

Private limited company sebagaimana disebut dalam paragraf di atas memiliki pertanggungjawaban terbatas. Pertanggungjawaban terbatas dalam konteks ini berarti bahwa utang perusahaan adalah merupakan utang perusahan itu sendiri dan pengurus dilindungi dari pertanggungjawaban pribadi, kecuali mereka melakukan kelalaian dalam pengurusan perusahaan atau memberikan personal guarantee. ${ }^{22}$

Pertanggungjawaban pemegang saham adalah terbatas pada jumlah modal yang disetujui untuk disetor kepada perusahaan. Jika jumlah tersebut telah dibayarkan secara penuh, maka pemegang saham tidak perlu lagi memberikan kontribusi apapun atas utang perusahaan. Jika jumlah tersebut belum dibayarkan secara penuh, maka tanggung jawab pemegang saham adalah sebatas jumlah yang belum disetorkan tersebut. ${ }^{23}$

${ }^{21}$ Rikvin, Singapore Private Limited Company Guide, Available at: http://www.rikvin.com/incorporation/singaporeprivate-limited-company/, Accessed 15 Juni 2013. Accounting and Corporate Regulatory Authority, Legal Nature of Companies, Available at: http://www.acra.gov.sg/NR/rdonlyres/EA3B81CAB14B-4B1F-A8FD00A9609DD5CD/0/LegalNatureofCompanies.pdf, Accessed 15 Juni 2013

${ }^{23}$ Ibid. 
Sehubungan dengan konsep pertanggungjawaban terbatas sebuah perusahaan, hukum memperlakukan perusahaan sebagai orang yang terpisah dengan pemegang saham dan pengurusnya.

Sebagaimana halnya prinsip Perseroan Terbatas di Indonesia, private limited company di Singapura adalah badan hukum yang memiliki kekayaan yang terpisah antara pemegang saham dengan perusahaan. Modal yang telah disetorkan oleh pemegang saham kepada perusahaan tidak lagi menjadi kekayaan pemegang saham melainkan milik perusahaan.

Temasek sebagai exempt private company memang mendapatkan keistimewaan yang tidak dinikmati oleh perusahaan-perusahaan lain. Keistimewaan tersebut adalah: Temasek tidak perlu mendaftarkan neraca keuangannya, temasek dapat meminjamkan uang kepada direktur dan perusahaannya (bahkan dimana direktur tersebut memiliki saham) dan Temasek mendapatkan keistimewaan berupa pengecualian dari kewajiban pembukaan data. $^{24}$ Namun keistimewaan yang diterima Temasek ini tidak melepaskan status Temasek sebagai private limited company yang tunduk pada the

${ }^{24}$ Anonim, Temasek Frequently Asked Questions, Available at: http://www.temasek.com.sg/faqs, Accessed 15 Juni 2013.
Singapore Companies Act. Temasek juga wajib membayar pajak dan menyetorkan deviden kepada pemegang saham (pemerintah Singapura).

Dengan tidak adanya pengecualian yang diberikan terhadap Temasek terkait dengan penyertaan modal pemerintah Singapura kepada Temasek, maka berarti kekayaan pemerintah Singapura yang disertakan pada Temasek dalam bentuk saham merupakan kekayaan Temasek. Kewajiban Temasek adalah membayarkan deviden (apabila mendapatkan keuntungan) kepada pemerintah Singapura sebagai pemegang saham. Hal ini sejalan dengan ketentuan the Singapore Companies Act mengenai private limited company sebagaimana telah dijelaskan di atas. Namun, oleh karena Temasek juga ditunjuk sebagai Fifth Schedule Entity berdasarkan konstitusi Singapura, maka Temasek memerlukan persetujuan dari Presiden Singapura terkait pengambilalihan past reserves. Hal inilah yang juga membedakan Temasek dengan private limited company pada umumnya.

Dengan demikian, berdasarkan ketentuan hukum Singapura, harta kekayaan negara yang disertakan dalam perusahaan negara yang berbentuk private limited company merupakan kekayaan perusahaan itu sendiri. 


\section{Akibat Hukum Kepemilikan Saham} Pemerintah Dalam Persero

Sebagai konsekuensi bahwa harta kekayaan negara yang disertakan dalam Persero adalah kekayaan Persero itu sendiri, maka pengelolaan harta kekayaan tersebut dilakukan sesuai dengan maksud dan tujuan didirikannya perseroan dengan berdasarkan good corporate governance. $^{25}$

Hal yang perlu diingat, adalah bahwa pengelolaan Persero tidak lepas dari keputusan-keputusan bisnis yang memiliki resiko menimbulkan kerugian bagi Persero, namun harus tetap dilakukan untuk mencegah kerugian lebih lanjut. Misalnya dalam hal kebijakan pengurangan pokok utang atau bunga (hair cut) kredit perbankan atau divestasi aset perusahaan.

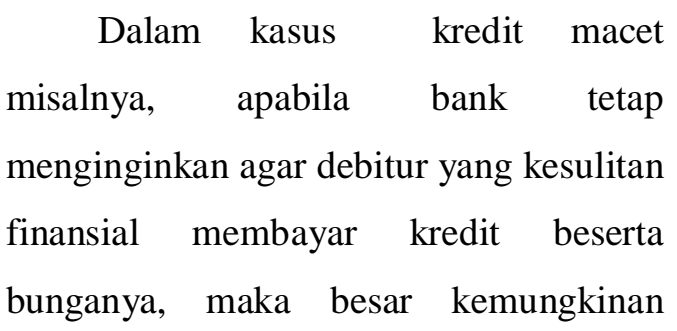

25 Secara umum, terdapat 5 prinsip Good Corporate Governance, yaitu: i) Transparency (keterbukaan informasi); ii) Accountability (akuntabilitas); iii) Responsibility (pertanggungjawaban); iv) Independency (kemandirian) dan v) Fairness (kesetaraan dan kewajaran).

\footnotetext{
Thomas S. Kaihatu, Good Corporate Governance dan Penerapannya di Indonesia, Available at: http://puslit.petra.ac.id/files/published/journals/MAN/ MAN060801/MAN06080101.pdf, Accessed 29 Januari 2013.
}

debitur tidak sanggup memenuhi kewajiban tersebut. Sehingga seringkali bank mengambil kebijakan untuk melakukan restrukturisasi utang, baik berupa keringanan cicilan maupun pengurangan bunga. Hal ini memang berakibat berkurangnya pendapatan yang seharusnya diterima bank, namun kebijakan tersebut dapat menghindarkan bank dari menumpuknya non performing loan yang dapat mengakibatkan kesulitan cash flow bank.

Saat ini, berdasarkan putusan Mahkamah Konstitusi Nomor 77/PUUIX/2011, BUMN dapat melakukan penyelesaian piutangnya dengan mekanisme korporasi dan tidak perlu diserahkan kepada Panitia Urusan Piutang Negara (PUPN). ${ }^{26}$ Hal ini memberikan fleksibilitas bagi Persero utamanya bank-bank Persero dalam melakukan restrukturisasi utang-utang krediturnya sehingga bank-bank Persero bisa lebih kompetitif. Sebelumnya,

${ }^{26}$ Majelis Mahkamah Konstitusi mengabulkan sebagian permohonan pengujian Pasal 4, Pasal 8, dan Pasal 12 ayat (1) UU No 49 Prp Tahun 1960 tentang Panitia Urusan Piutang Negara. Mahkamah membatalkan frasa "badan-badan negara" dalam pasalpasal itu. Artinya, secara tersirat Mahkamah Konstitusi menyatakan piutang badan usaha yang dikuasai negara (bank BUMN) tidak perlu menyerahkan piutang (tagihan) kepada PUPN lagi.

Hukum Online, MK Rombak Aturan Piutang BUMN, Available http://www.hukumonline.com/berita/baca/lt5061a7c18 afe 5/mk-rombak-aturan-piutang-bumn, Accessed 9 Juli 2013. 
berdasarkan UU No. 49 Prp. Tahun 1960, piutang BUMN harus diselesaikan oleh PUPN. Penyelesaian piutang melalui PUPN ini menyulitkan bank-bank Persero untuk mengurangi non performing loan yang menumpuk, sehingga tidak bisa bergerak sebebas bank-bank swasta.

Selanjutnya, dalam pengelolaan Persero, tidak dapat lepas dari pengadaan barang dan jasa guna memenuhi kebutuhan Persero. Pengadaan barang dan jasa di lingkungan Persero tidaklah tunduk pada ketentuan pengadaan barang dan jasa sebagaimana ditentukan dalam APBN, melainkan tunduk pada ketentuan pengadaan barang dan jasa yang di lingkungan Persero itu sendiri. Hal ini menegaskan prinsip bahwa kekayaan negara yang disertakan dalam Persero, merupakan kekayaan Persero itu sendiri yang pengelolaannya dilakukan dengan prinsip GCG. Hal ini ditegaskan dalam Surat Edaran Kementerian Negara BUMN nomor S- 298/S.MBU/2007, tanggal 25 Juni $2007 .^{27}$

Dengan tidak berlakunya ketentuan Keppres Nomor 80 Tahun 2003 dalam pengadaan barang dan jasa di lingkungan

27 Berdasarkan Surat Edaran Kementerian Negara BUMN nomor S- 298/S.MBU/2007, tanggal 25 Juni 2007 perihal Pelaksanaan pengadaan barang dan jasa BUMN, bagi pengadaan barang dan jasa BUMN yang dananya berasal dari dana BUMN, tidak berlaku Keppres Nomor 80 Tahun 2003 tentang Pedoman Pelaksanaan Pengadaan Barang/Jasa Pemerintah (termasuk perubahannya).
Persero yang pengadaannya tidak berasal dari dana APBN, maka Persero wajib memiliki pedoman pengadaan barang dan jasa. Pedoman ini penting untuk menjamin bahwa pengadaan barang dan jasa di lingkungan Persero dilakukan secara transparan, akuntabel dan fair untuk keuntungan Persero semata-mata serta menjamin bahwa barang dan jasa yang diterima Persero adalah sesuai dengan yang dibutuhkan Persero dengan harga yang paling kompetitif.

Terkait dengan audit Persero, audit tidak hanya dilaksanakan oleh komite audit internal dan akuntan publik sebagaimana diamanatkan dalam UU No. 19 tahun 2003 dan UU No. 40 tahun 2007. Badan Pemeriksa Keuangan (BPK) dapat melakukan audit terhadap Persero sebagai akibat UU No. 17 tahun 2003 dan UU No.1 tahun 2004 masih menganggap bahwa kekayaan Persero adalah keuangan negara. Diberikannya kewenangan bagi BPK untuk memeriksa laporan keuangan Persero merupakan inkonsistensi atas prinsip pemisahan kekayaan negara dalam Persero. Kekayaan negara yang telah disertakan dalam Persero tidaklah lagi merupakan kekayaan negara, sehingga seharusnya tidak menjadi domain BPK.

Sebagaimana telah disebutkan di atas bahwa sebagai badan hukum maka terdapat pemisahan kekayaan antara negara sebagai pemegang saham dengan 
Persero. Pemisahan inilah yang menyebabkan Persero sebagai badan hukum dapat melakukan kontrak dengan pihak ketiga, bahkan dengan Persero lainnya dan setiap kontrak yang dibuat oleh Persero hanyalah mengikat Persero tersebut dan tidak mengikat negara.

Hal ini menjadi jelas ketika Persero menjadi kreditur dalam perkara kepailitan. Piutang Persero akan diberlakukan sama seperti perseroan terbatas pada umumnya, kecuali terhadap piutang Persero tersebut melekat hak-hak istimewa sehingga Persero dapat memperoleh pelunasan piutang terlebih dahulu (misalnya hak tanggungan, fidusia). Selebihnya, Persero tidak dapat meminta agar piutangnya diperlakukan sebagai piutang negara yang wajib mendapatkan prioritas pelunasan. ${ }^{28}$

Bagaimana jika Persero yang tidak mampu memenuhi kewajibannya dalam kontrak? Dalam hal demikian, pihak ketiga yang haknya tidak dipenuhi oleh Persero dapat mengajukan gugatan wanprestasi ke pengadilan atau permohonan arbitrase. Apabila ada tuntutan hukum terhadap Persero dan pengadilan memerintahkan dilakukan penyitaan terhadap kekayaan Persero, maka Persero tidak bisa meminta agar

${ }^{28}$ Berdasarkan Pasal 55 UU No. 37 tahun 2004, keistimewaan atas pemenuhan piutang Persero hanya dapat dilakukan apabila Persero merupakan pemegang gadai, jaminan fidusia, hak tanggungan, hipotek, atau hak agunan atas kebendaan lainnya. pengadilan mencabut sita dengan berlindung pada alasan bahwa kekayaan tersebut adalah kekayaan negara yang tidak bisa disita sebagaimana diatur dalam UU No. 1 tahun 2004.

Dalam prakteknya, aset Persero dapat disita sebagai jaminan pemenuhan kewajiban Persero. Misalnya dalam perkara gugatan yang diajukan oleh Alexander Gee terhadap PT Djakarta Lloyd (Persero), majelis hakim pada PN Jakarta Pusat mengabulkan sita jaminan yang diajukan oleh penggugat. ${ }^{29}$

Dalam hal Persero terlibat dalam bisnis dengan resiko tinggi dan modal yang sangat besar, seperti bisnis minyak dan gas bumi, atau pembangunan infrastuktur seperti jalan tol, perusahaan akan membentuk anak bahkan cucu perusahaan sebagai bentuk ring fencing guna meminimalkan resiko pada induk perusahaan. Dalam proyek yang memerlukan modal sangat besar, anak perusahaan tersebut dapat menggunakan instrumen project finance untuk membiayai proyek tersebut. Pilihan untuk menggunakan skema project finance untuk membiayai proyek didasari oleh lebih kecilnya resiko yang harus ditanggung oleh induk perusahaan.

Pada skema pembiayaan dengan project finance, jaminan terhadap kredit

29 Anonim, Kapal Djakarta Lloyd Disita, available at: http://www.hukumonline.com/berita/baca/hol21318/ka pal-djakarta-lloyd-disita, accessed at 12 Oktober 2013. 
yang diberikan oleh kreditur tidak berasal dari aset perusahaan induk. Jaminan atas kredit berasal dari aset project company (yang dibentuk khusus untuk melaksanakan project tersebut), aset proyek, dokumen-dokumen proyek dan cash flow proyek. $^{30}$

Seringkali karena proyek yang dikerjakan oleh project company memiliki resiko sangat tinggi dan memerlukan biaya yang sangat besar, maka kreditur yang merupakan bank luar negeri atau sindikasi bank luar negeri meminta limited guarantee kepada perusahaan induk. Dalam kasus seperti ini Persero tidak bisa bertindak sebagai penjamin project company. Keputusan Presiden No. 59 Tahun 1972 melarang Persero untuk bertindak sebagai penjamin atas kredit luar negeri yang diterima oleh anak perusahaan. ${ }^{31}$

Hal lain yang menjadi kendala bagi Persero untuk menjadi penjamin bagi anak perusahaan adalah ketentuan World Bank negative pledge. Negara yang menerima pembiayaan dari World Bank

30 Latham \& Watkins, The Book of Project Finance Jargon, The Latham \& Watkins Glossary of Project Development, Acquisition and Finance Slang and Terminology, First Edition, h.74.

${ }^{31}$ Pasal 3 ayat (2) keputusan Presiden Republik Indonesia Nomor 59 Tahun 1972 Tentang Penerimaan Kredit Luar Negeri:

Badan Usaha Negara dan Badan Usaha Daerah tidak dibenarkan untuk memberikan jaminan atau bertindak selaku penjamin dalam pembayaran kembali kredit luar negeri yang diterima oleh Badan Usaha Negara, Badan Usaha Daerah, dan Perusahaan Swasta. akan tunduk pada negative pledge restriction. $^{32}$

Berdasarkan ketentuan negative pledge, negara debitur World Bank tidak dapat menjaminkan aset publiknya kepada kreditur lain, kecuali atas persetujuan World Bank. ${ }^{33}$ Indonesia sebagai debitur World Bank terikat pada ketentuan tersebut, sehingga pemerintah tidak dapat menjaminkan aset publiknya, kecuali telah mendapat persetujuan dari World Bank. Yang menjadi perdebatan adalah definisi dari aset publik itu sendiri. Apakah aset publik yang dimaksud adalah hanya barang milik negara atau juga mencakup kekayaan BUMN.

Apabila konsisten dengan prinsip bahwa Persero adalah badan hukum, maka tentu saja kekayaan Persero tidak termasuk sebagai aset publik. Namun demikian, oleh karena ketentuan UU No. 17 tahun 2003 masih menganggap bahwa kekayaan Persero merupakan aset publik maka tunduk pada ketentuan World Bank negative pledge.

Hal ini tentu saja akan menyulitkan Persero untuk mengembangkan usahanya. Apalagi jika Persero bergerak di bidang usaha yang sarat modal dan resiko. Hal ini menyulitkan Persero untuk bergerak

32 Norton Rose, Infrastructure updater: New opportunities and challenges for 2012, Available at: http://www.nortonrosefulbright.com/knowledge/public ations/61755/infrastructure-updater-new-opportunitiesand-challenges-for-2012, Accessed 9 Juli 2013.

33 International Bank for Reconstruction and Development, 2010, General Conditions for Loans, Section 6.02 a, h. 17 . 
secara agresif mengembangkan bisnisnya.

Pada akhirnya Persero pun kesulitan untuk mewujudkan tujuan dibentuknya Persero itu sendiri, yakni untuk mengejar keuntungan.

\section{Bagaimana dengan Temasek?}

Sebagaimana telah dijelaskan di atas bahwa Temasek adalah exempt private company. Artinya, Temasek sebagai Government Linked Company merupakan perusahaan swasta yang dibatasi saham (sebagaimana Persero di Indonesia). Sebagai exempt private company, Temasek mendapatkan keistimewaan berupa tidak perlu mendaftarkan neraca keuangannya dan dibebaskan dari kewajiban pembukaan data. Namun selebihnya, Temasek beroperasi sebagaimana perusahan swasta yang bertujuan untuk mengejar keuntungan.

Dimilikinya 100 persen saham Temasek oleh pemerintah Singapura tidak menyebabkan dilakukannya intervensi oleh pemerintah atas keputusan-keputusan bisnis Temasek. Presiden Singapura misalnya tidak terlibat dalam keputusan-keputusan bisnis yang diambil Temasek terkait investasi, divestasi atau keputusan bisnis atau manajemen lainnya. Peran Presiden Singapura hanya sebatas pada custodial role untuk melindungi Past Reserves mengingat status Temasek sebagai Fifth Schedule Entity berdasarkan konstitusi Singapura. Hal yang sama juga berlaku bagi pemerintah Singapura. Pemerintah Singapura tidak terlibat dalam keputusan bisnis, manajemen maupun operasional Temasek. $^{34}$

Temasek terlibat dalam berbagai jenis investasi, seperti manufaktur, jual beli, perbankan dan sebagainya serta mengumpulkan pendanaan di pasar uang komersial. Pemerintah Singapura sebagai pemegang saham Temasek tidak terlibat dalam keputusan-keputusan investasi dan operasional perusahaan. Seluruh keputusan bisnis dan investasi diambil secara independen oleh board of Temasek's Senior Managing Director of Investment berdasarkan pertimbangan komersial. ${ }^{35}$

Pada awal pendiriannya, Temasek memiliki nilai investasi sebesar USD 345 juta yang tersebar dalam 36 perusahaan. Tugas Temasek adalah memonitor perkembangan investasinya dan memberi informasi kepada Menteri Keuangan dan kabinet sebagai pemegang saham. Pada tahun 2005, nilai investasi Temasek berkembang menjadi USD 103 miliar yang tersebar dalam 200 perusahaan. Temasek memiliki lebih dari 20 persen

34 Temasek, Frequently Asked Questions, available http://www.temasek.com.sg/abouttemasek/faqs accessed 1 Juni 2013.

35 Anthony Shome, Singapore's State Guided Entrepreneurship: A Model For Transnational Economies?, New Zealand Journal of Asian Studies 11, June 2009 h.318-336, Available at: http://www.nzasia.org.nz/downloads/NZJASJune09/23_Shome 3.pdf, Accessed at 31 Januari 2013. 
saham pada 68 persen anak-anak perusahaannya (GLC), sehingga memberikan hak pengendalian bagi Temasek. $^{36}$ Adapun net portfolio Temasek adalah sebesar S\$215 miliar pada tanggal 31 Maret 2013. ${ }^{37}$

Temasek sebagai GLC beroperasi berdasarkan prinsip komersial. Temasek tidak menerima subsidi atau perlakuan istimewa dari pemerintah dan tunduk pada peraturan dan keadaan pasar yang sama dengan perusahaan swasta. ${ }^{38}$

Dalam hal ini dapat dilihat bahwa status Temasek sebagai GLC tidak menghambat Temasek dalam melakukan pengelolaan perusahaan yang semaksimal mungkin untuk keuntungan perusahaan. Bahkan status Temasek sebagai GLC dan exempt private company memberikan Temasek beberapa keuntungan yang tidak dinikmati perusahaan swasta lainnya. Hal ini memudahkan Temasek untuk berkembang hingga sampai pada posisinya sekarang.

Selain itu Temasek sebagai limited liability company beroperasi dengan basis komersial. Dengan demikian, Temasek diperlakukan sama seperti limited liability company lainnya, dimana Temasek leluasa untuk berkontrak dengan pihak manapun untuk mencapai tujuan

\section{${ }^{36}$ Ibid.}

37 Anonim, Temasek Review, Available at http://www.temasekreview.com.sg/\#overviewfromOurChairman, Accessed at 13 Agustus 2013

${ }^{38}$ Anthony Shome, Loc. Cit. perusahaan. Temasek juga dapat menjadi penjamin bagi anak perusahaannya.

Sebagai contoh, pada tanggal 14 September 2005, salah satu anak perusahaan Temasek, yakni Temasek Financial (I) Limited mengeluarkan US\$10,000,000,000 Guaranteed Global Medium Term Note Program yang dijamin sepenuhnya oleh Temasek. $^{39}$ Dengan keleluasaan yang dimiliki tersebut dan pengelolaan yang efisien tidak heran jika Temasek menjadi salah satu contoh perusahaan milik negara yang paling sukses.

Sebaliknya dengan Persero, kedudukan Persero sebagai perseroan terbatas yang seluruh atau sebagian besar modalnya dikuasai negara justru menyebabkan Persero kurang kompetitif. Pengelolaan kekayaan Persero seharusnya bisa lebih leluasa mengingat semangat dasar dari dibentukanya perseroan terbatas adalah untuk melindungi pemegang saham sebatas modal yang disetor. Namun beberapa inkonsistensi dalam memandang dan memperlakukan kekayaan negara yang disertakan dalam Persero mengakibatkan Persero sulit untuk berkompetisi dengan perusahaan - perusahaan swasta. Terlebih apabila Persero tersebut bergerak di

\footnotetext{
${ }^{39}$ Anonim, Offering Circular Temasek Financial (I) Limited, available at:
http://www.temasek.com.sg/Documents/userfiles/files/ Temasek_Program_Offering_Circular\%20_dated_12Ju 1y2013.PDF, accessed at 12 Oktober 2013.
} 
bidang usaha yang sarat resiko dan modal. Sehingga diperlukan sinkronisasi peraturan perundangan terkait kekayaan negara yang disertakan dalam Persero agar kedepannya Persero bisa lebih kompetitif dan menjadi tulang punggung ekonomi bangsa.

\section{SIMPULAN DAN SARAN}

\section{Simpulan}

a. Berdasarkan hukum perseroan di Indonesia, harta kekayaan negara yang dijadikan sebagai penyertaan modal dalam Persero merupakan kekayaan Persero yang terpisah dari keuangan negara. Adapun menurut hukum perseroan Singapura, kekayaan negara yang disertakan dalam GLC adalah kekayaan GLC itu sendiri..

b. Akibat hukum kepemilikan saham pemerintah dalam Persero adalah, pengelolaannya tidak lagi tunduk pada prinsip-prinsip APBN, melainkan pada prinsip GCG. Kontrak-kontrak yang dibuat Persero hanya mengikat Persero dan tidak mengikat negara.

Kepemilikan saham pemerintah Singapura pada Temasek mengakibatkan kekayaan Temasek dikelola dengan mekanisme korporasi dan nyaris tanpa intervensi pemerintah (kecuali untuk past reserves) sehingga Temasek leluasa untuk berkontrak dengan pihak lain dan bisa menjadi penjamin bagi anak perusahaannya

\section{Saran}

a. Untuk konsistensi peraturan perundangundangan dan sesuai dengan prinsip Perseroan Terbatas sebagai badan hukum, perlu dilakukan perubahan terhadap ketentuan Pasal 2 huruf g UU No. 17 tahun 2003 dan Pasal 1 angka 1 dan Pasal 71 ayat (2) UU No. 1 tahun 2004 sehingga tidak lagi muncul perbedaaan interpretasi dalam memandang kedudukan kekayaan negara yang disertakan dalam Persero.

b. Diperlukan kesepahaman dan konsistensi diantara pemerintah maupun penegak hukum dalam perlakuan terhadap Persero. Sebagai badan hukum yang berbentuk Perseroan Terbatas, sudah seharusnya Persero diperlakukan sebagaimana Perseroan Terbatas dan bukan lembaga negara, sehingga Persero dapat berkembang dengan lebih optimal dan mampu menjadi tulang punggung ekonomi bangsa.

\section{DAFTAR PUSTAKA}

Bambang Sunggono, 2006, Metodologi Penelitian Hukum, PT RajaGrafindo Persada, Jakarta.

Chidir Ali, 1999, Badan Hukum, Alumni, Bandung.

Gunawan Widjaja, 2008, Resiko Hukum Sebagai Direksi, Komisaris dan Pemilik $P T$, Forum Sahabat, Jakarta.

Gunawan Widjaja, 2008, Hak Individu dan Kolektif Para Pemegang Saham, Forum Sahabat, Jakarta.

Ha Joon Chang, 2007, State Owned Enterprise Reform, United Nation 
Department For Economic And Social Affair.

IG Rai Widjaja, 1994, Pedoman Dasar Perseroan Terbatas (PT), Pradnya Paramita, Jakarta.

International Bank for Reconstruction and Development, 2010, General Conditions for Loans.

Latham \& Watkins, 2011, The Book of Project Finance Jargon, The Latham \& Watkins Glossary of Project Development, Acquisition and Finance Slang and Terminology, First Edition.

Peter Mahmud Marzuki, 2009, Penelitian Hukum, Kencana Prenada Media Group, Jakarta.

R. Ali Ridho 2001, Badan Hukum dan Kedudukan Badan Hukum Perseroan, Perkumpulan, Korporasi, Yayasan , Wakaf, Alumni, Bandung.

Soerjono Soekanto dan Sri Mamudji, 2001 Penelitian Hukum Nornatif Suatu Tinjauan Singkat, PT RajaGrafindo Persada, Jakarta.

\section{ARTIKEL ELEKTRONIK}

Accounting and Corporate Regulatory Authority, Legal Nature of Companies, Available at: http://www.acra.gov.sg/NR/rdonlyres/E A3B81CA-B14B-4B1F-A8FD00A9609DD5CD/0/LegalNatureofCom panies.pdf, Accessed 15 Juni 2013.

Accounting and Corporate Regulatory Authority, Private Company Limited by Shares, Available at: http://www.acra.gov.sg/Company/Starti ng_a_Company/Types+of+Companies. htm, Accessed 15 Juni 2013.

Anonim, Kapal Djakarta Lloyd Disita, available at: http://www.hukumonline.com/berita/ba ca/hol21318/kapal-djakarta-lloyd-disita, accessed at 12 Oktober 2013.

Anonim, Offering Circular Temasek Financial (I) Limited, available at: http://www.temasek.com.sg/Documents /userfiles/files/Temasek_Program_Offer ing_Circular\%20_dated_12July2013.P DF, accessed at 12 Oktober 2013.

Anonim, Temasek Frequently Asked Questions, Available at: http://www.temasek.com.sg/faqs, Accessed 16 Juni 2013.

Anonim, Temasek Review, Available at http://www.temasekreview.com.sg/\#ove rview-fromOurChairman, Accessed at 13 Agustus 2013.

Anthony Shome, Singapore's State Guided Entrepreneurship: A Model For Transnational Economies?, New Zealand Journal of Asian Studies 11, June 2009 h.318-336, Available at: http://www.nzasia.org.nz/downloads/N ZJAS-June09/23_Shome_3.pdf, Accessed at 31 Januari 2013.

Business Week, Company Overview of Temasek Holdings (Private) Limited, Available at: http://investing.businessweek.com/resea rch/stocks/private/snapshot.asp?privcap $\mathrm{Id}=107637$, Accessed 15 Juni 2013.

Hukum Online, MK Rombak Aturan Piutang $B U M N, \quad$ Available at: http://www.hukumonline.com/berita/ba ca/lt5061 a7c18afe5/mk-rombak-aturanpiutang-bumn, Accessed 9 Juli 2013.

Kementerian Badan Usaha Milik Negara, Laba Rugi, available at: http://www.bumn.go.id/kinerjabumn/laba-rugi/, accessed 07 Oktober 2013

Moody's Investor Service, Credit Opinion: Temasek Holdings (Private) Limited, Available at. http://www.temasek.com.sg/Documents /userfiles/files/Moody's_Ratings_Updat e_5_Dec_12.pdf, Accessed 18 September 2013.

Norton Rose, Infrastructure updater: New opportunities and challenges for 2012, Available at: http://www.nortonrosefulbright.com/kn owledge/publications/61755/infrastructu re-updater-new-opportunities-andchallenges-for-2012, Accessed 9 Juli 2013.

Ridwan Khairandy, Konsepsi Kekayaan Negara Dipisahkan dalam Perusahaan Perseroan, Jurnal Hukum Bisnis, Vo.26-No.1, 2007.

Rikvin, Singapore Private Limited Company Guide, Available at: http://www.rikvin.com/incorporation/si 
ngapore-private-limited-company/, Accessed 15 Juni 2013.

Standard and Poor's Rating Service, Rating Direct, Summary Temasek Holding (Private) Limited, Available at http://www.temasek.com.sg/Documents /userfiles/files/SP_Temasek_SA_2013_ Jun_28.pdf, accessed at 18 September 2013.

Thomas S. Kaihatu, Good Corporate Governance dan Penerapannya di Indonesia, Available at: http://puslit.petra.ac.id/files/published/j ournals/MAN/MAN060801/MAN0608 0101.pdf, Accessed 29 Januari 2013.

\section{BIODATA PENULIS}

Nama lengkap dengan gelar:

Ni Wayan Desi Aryanti, S.H.

Alamat rumah:

Jl. P. Saelus I No. 12X Denpasar.

Tempat bekerja:

PT Pertamina (Persero).

HP

085737295478

Alamat e-mail.

niwayandesi@gmail.com 